pISSN: 2301-7716; eISSN: 2622-4607

Suardhika dkk.

Jurnal Farmasi Udayana, Vol 7, No 2, Tahun 2018, 38-43

\title{
Perbandingan Pengaruh Lama Pengeringan Terhadap Rendemen Minyak Atsiri Kulit Jeruk Manis (Citrus sinensis) dengan Destilasi Uap dan Identifikasi Linalool dengan KLT-Spektrofotodensitometri
}

\author{
Suardhika, I.M. ${ }^{1 *}$, I.P.A.A. Pratama ${ }^{1}$, P.B.P.P. Budiartha ${ }^{1}$, L.P.I. Partayanti ${ }^{1}$, N.L.P.V.Paramita ${ }^{1}$ \\ ${ }^{1}$ Program Studi Farmasi Fakultas Matematika dan Ilmu Pengetahuan Alam Universitas Udayana, \\ Jalan Kampus Unud, Jimbaran, 80364 \\ *E-mail:imadesuardhika@gmail.com
}

\begin{abstract}
ABSTRAK
Penelitian ini bertujuan untuk mengetahui pengaruh lama pengeringan terhadap rendemen minyak atsiri yang dihasilkan dari sampel kulit jeruk manis (Citrus sinensis) dan identifikasi keberadaan senyawa linalool dari minyak atsiri. Sampel kulit jeruk manis masing-masing sebanyak 300 gram dikeringkan suhu $40^{\circ} \mathrm{C}$ menggunakan oven dengan perlakuan pengeringan 0 jam atau segar (sampel 1), pengeringan 24 jam (sampel 2), dan 48 jam (sampel 3). Proses ekstraksi dilakukan dengan metode destilasi uap dengan pencapaian perolehan destilat sebanyak $500 \mathrm{~mL}$. Minyak atsiri dipisahkan dari destilat dengan menggunakan ekstraksi cair-cair sehingga diperoleh minyak atsiri secara maksimal. Hasil rendemen minyak atsiri tertinggi diperoleh pada sampel dengan perlakukan pengeringan selama 48 jam yaitu sebesar 0,5\% (MA3), pengeringan 24 jam diperoleh rendemen sebesar 0,4\% (MA2) dan sampel tanpa pengeringan memberikan rendemen paling kecil yaitu $0,2 \%$ (MA1). Identifikasi senyawa linalool dengan menggunakan KLT-Spektofotodensitometri dilakukan untuk mengetahui besaran kandungan linalool dilihat dari nilai AUC (Area Under Curve) yang dihasilkan, dan didapatkan AUC untuk MA3 sebesar 39475, MA 2 sebesar 35889, dan MA1 sebesar 8980. Berdasarkan data yang diperoleh maka dapat disimpulkan bahwa lama pengeringan sampel berpengaruh terhadap rendemen minyak atsiri dan senyawa linalool yang diperoleh.
\end{abstract}

Kata Kunci: Citrus sinensis, minyak atsiri, linalool, destilasi uap, pengeringan,

\section{ABSTRACT}

This study aims to determine the effect of drying time on the yield of essential oils from orange peel (Citrus sinensis) and identify the presence of linalool compounds from essential oils. 300 grams of orange skin samples were dried at $40^{\circ} \mathrm{C}$ using an oven with a drying treatment of 0 hours (fresh), 24 hours, and 48 hours. The extraction process is carried out by steam distillation method with attainment of $500 \mathrm{ml}$ of distillate. Essential oils are separated from water using liquidliquid extraction (LLE), so that the essential oils are maximally obtained. The highest yield of essential oil obtained in the sample with a drying treatment for 48 hours is $0.5 \%$ (MA3), 24-hour drying obtained a yield of $0.4 \%$ (MA2) and the sample without drying provides the smallest yield of $0.2 \%$ (MA1). Identification of linalool compounds using TLC-Spectrophotodensitometry was carried out to determine the amount of linalool content seen from the AUC (Area Under Curve). AUC MA3 sample is 39475, MA2 is 35889, and MA1 is 8980 . Based on the data obtained can be concluded that the drying duration of the sample affects the yield of essential oils and linalool compounds that obtained.

Keyword: Citrus sinensis, essential oil, linalool, steam destilation, drying, 
pISSN: 2301-7716; eISSN: 2622-4607

Suardhika dkk.

Jurnal Farmasi Udayana, Vol 7, No 2, Tahun 2018, 38-43

\section{PENDAHULUAN}

Indonesia adalah salah satu negara yang beriklim tropis sehingga menjadikan indonesia kaya akan berbagi jenis flora fauna yang dimiliki. Indonesia memiliki sekitar 25.000-30.000 spesies tanaman yang menjadikan indonesia sebagai negara terkaya nomor dua di dunia setelah Brazil dalam hal kekayaan biodiversitasnya (Pramono, 2002). Pola hidup masyarakat yang cendrung lebih memilih produk herbal daripada produk sintesis membuka peluang besar dalam pasar sesuai dengan permintaan yang ada.

Minyak atsiri atau essential oil adalah metabolit sekunder yang dihasilkan oleh tanaman dan sebagai salah satu komoditas yang memiliki permintaan pasar yang besar. Minyak atsiri biasanya berwujud cair dan memiliki aroma khas sesuai dengan sumber tanamannya. Pemanfaatan minyak atsiri sangat luas mulai dari kosmetika, parfum, industri makanan dan minuman, sampai industri obat-obatan (Julianto, 2016).

Ekstraksi minyak atsiri dapat dilakukan dengan berbagai cara seperti destilasi, enflurge, esktrasi dengan pelarut non polar, sampai yang terbaru adalah metode Supercritical Fluid Extraction (SFE). Metode ekstraksi yang paling umum digunakan adalah dengan destilasi. Destilasi adalah suatu metode pemisahan analit dari komponennya dengan menggunakan prinsip dasar perbedaan titik didih. Destilasi dapat dibagi menjadi tiga jenis yaitu destilasi air, destilasi uap, dan destilasi uap-air (Gandjar dan Rohman, 2007).

Kulit jeruk manis (Citrus sinensis) merupakan salah satu sumber minyak atsiri yang sangat potensial karena pemanfaatannya yang masih belum maksimal dan lebih banyak menjadi limbah. Minyak atsiri kulit jeruk mengandung berbagai komponen di dalamnya antara lain limonene, linalool, $\alpha$-pinen, $\beta$-pinen, mirsen, oktanal, dekanal. Dengan komponen limonene dan linalool adalah komponen mayor yang ada didalamnya (Alfianur, 2017). Linalool yang merupakan salah satu senyawa mayor dalam minyak atsiri kulit jeruk manis memiliki efek farmakologis yang luas seperti antioksidan, anti aging, antibakteri, dan antivirus (Zahra dan Iskandar, 2017).

Jumlah rendemen minyak atsiri yang diperoleh, berdasarkan penelitian-penelitian yang dilakukan sebelumnya, meningkat seiring dilakukannya pra-perlakuan pada sampel. Salah satu metode pra-perlakuan yang umum dilakukan adalah pengeringan. Pengeringan pada sampel akan mengurangi kadar air dan kelembaban pada sampel yang akan menyebabkan terbukanya poripori sel pada tanaman yang akan diekstraksi (Sunardi dkk. 2009).

Penelitian yang dilakukan oleh Sunardi dkk. (2008) menyebutkan bahwa pola pengeringan sampel berpengaruh terhadap rendemen minyak atsiri daun nilam yang diperoleh. Nugraheni dkk. (2016) melaporkan bahwa rendemen minyak atsiri daun kayu manis meningkat dengan dilakukannya perlakuan awal pada sampel dengan cara kering angin. Menurut penelitian Muhtadin dkk. (2013) kualitas minyak atsiri kulit jeruk meningkat seiring pretreatmen pengeringan dengan menggunakan oven.

Penelitian ini bertujuan untuk mengetahui pengaruh lama pengeringan sampel terhadap rendemen minyak atsiri dan identifikasi senyawa linalool menggunaan KLTspektofotodensitometri kulit buah jeruk manis (Citrus sinensis). Manfaat dari penelitian ini adalah sebagai sumber informasi bagi masyarakat, produsen, dan peneliti dalam meningkatkan hasil produksi minyak atsiri.

\section{BAHAN DAN METODE}

\subsection{Bahan}

Bahan yang digunakan pada penelitian ini adalah kulit buah jeruk, akuades, toluene p.a, etil asetat p.a, etanol 95\% teknis, metanol teknis, $\mathrm{NaCl}$, kloroform p.a, asam asetat anhidrat, dan asam sulfat pekat.

\subsection{Alat}

Alat yang digunakan pada penelitian ini adalah seperangkat alat destilasi uap, dan seperangkat alat TLC spektrofotodensitometer (Camag $\left.{ }^{\circledR}\right)$, chamber (Camag $\left.{ }^{\circledR}\right)$, UV cabinet (Camag $\left.{ }^{\circledR}\right)$, oven (Binder $\left.{ }^{\circledR}\right)$. 
pISSN: 2301-7716; eISSN: 2622-4607

Suardhika dkk.

Jurnal Farmasi Udayana, Vol 7, No 2, Tahun 2018, 38-43

\subsection{Metode Penelitian Penyiapan bahan}

Sampel kulit jeruk diperoleh dari toko buah segar di daerah Jimbaran, Kabupaten Badung, Provinsi Bali Sampel kulit jeruk dikupas kemudian dibersihkan dan dipotong-potong dengan ukuran $\pm 2 \mathrm{~cm} \times 2 \mathrm{~cm}$. Sampel Kulit jeruk diambil sebagian dan dilakukan pengecilan ukuran partikel yang nantinya akan dilakukan skrining terpenoid dan minyak atsiri. Kulit buah jeruk yang telah dipotong, dikeringkan oven selama 24 jam dengan suhu $40^{\circ} \mathrm{C}$ untuk percobaan satu. Kulit jeruk dikeringkan selama 48 jam pada suhu $40^{\circ} \mathrm{C}$ untuk pecobaan dua. Kulit buah jeruk yang masih segar digunakan untuk percobaan ketiga. Masingmasing sampel disiapkan dengan bobot 300 gram.

\section{Skrining Fitokimia Ekstrak}

Kulit buah jeruk kering dikecilkan ukuran partikelnya dengan menggunakan blender dan diayak dengan ayakan 40 mesh. Sedangkan kulit buah jeruk segar dipotong dan dikecilkan ukuran partikelnya. Sampel kulit buah jeruk masing masing sebanyak 20 gram diekstraksi dengan 120 $\mathrm{mL}$ etanol $95 \%$.

\section{a. Identifikasi Minyak Atsiri}

Larutan uji dipipet sebanyak $1 \mathrm{~mL}$ dan diuapkan diatas cawan porselen hingga diperoleh residu. Bau yang khas dari residu menunjukkan hasil positif dari minyak atsiri (Khotimah, 2016).

\section{b. Identifikasi Terpenoid}

Larutan uji sebanyak $2 \mathrm{~mL}$ diuapkan diatas cawan porselen dan residu dilarutkan kloroform lalu ditambahkan asam asetat anhidrat sebanyak $0,5 \mathrm{ml}$, ditambahkan $2 \mathrm{ml}$ asam sulfat pekat melalui dinding tabung. Terbentuknya cincin kecoklatan atau violet pada perbatasan larutan menujukkan adanya triterpenoid (Padmasari dkk., 2013).

\section{Destilasi}

Keruk sampel 1, sampel 2, dan sampel 3 dimasukan ke dalam labu ekstraktor pada hari yang berbeda. Laju Pemanasan diatur pada proses penyulingan lalu ditunggu sampai tetes pertama destilat keluar dari kondensor. Destilasi dihentikan setelah diperoleh volume destilat 500 $\mathrm{mL}$. Minyak dan air dipisahkan menggunakan corong pemisah lalu ditampung minyak tersebut pada tabung reaksi. Fase minyak diambil dengan penambahan $\mathrm{NaCl}$ sampai fase minyaknya terpisah sempurna (Muhtadin dkk, 2013). Fase minyak dipipet dan dipindahkan ke botol sampel serta dilakukan perhitungan terhadap rendemen minyak yang dihasilkan dengan rumus berikut :

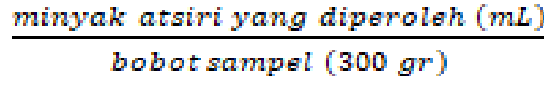

\section{Identifikasi Linalool Secara Kualitatif a. KLT Minyak Atsiri}

Ketiga sampel minyak atsiri ditotolkan dengan volume penotolan $8 \mu \mathrm{L}$ pada fase diam plat KLT silika gel GF254 dengan ukuran 2 x 10 $\mathrm{cm}$. Fase gerak toluen : etil asetat (93:7).

\section{b. Identifikasi}

Identifikasi dilakukan dengan pengamatan pada spot yang terbentuk di atas plat yang telah dielusi pada sinar UV $254 \mathrm{~nm}$ dan $366 \mathrm{~nm}$. Fluoresensi biru menunjukkan hasil positif minyak atsiri pada sinar UV $366 \mathrm{~nm}$.

\section{c. Analisis Kualitatif dengan KLT- Spektrofotodensitometri}

Senyawa linalool memiliki panjang gelombang maksimum pada $235 \mathrm{~nm}$. Spot yang diduga linalool diamati dengan spektrofotodensitometer dengan melihat kemiripan dengan spektrum pustaka dan nilai AUC (Desmiaty dkk, 2017).

\section{HASIL}

Rendemen minyak atsiri adalah perbandingan antara hasil minyak atsiri yang didapatkan dari proses destilasi dengan bahan baku yang diekstraksi. Hasil rendemen minyak atsiri dapat dilihat pada Tabel 1.

Berdasarkan data yang ditunjukan pada Tabel 1 dapat dilihat bahwa rendemen minyak atsiri yang diperoleh meningkat seiring dilakukannya pengeringan pada sampel. 
pISSN: 2301-7716; eISSN: 2622-4607

Suardhika dkk.

Jurnal Farmasi Udayana, Vol 7, No 2, Tahun 2018, 38-43

Tabel 1. Rendemen Minyak Atsiri Hasil Destilasi

\begin{tabular}{cccc}
\hline No & Sampel & $\begin{array}{c}\text { Volume } \\
\text { destilat }\end{array}$ & $\begin{array}{c}\text { Rendemen } \\
\% \mathrm{v} / \mathrm{v}\end{array}$ \\
\hline 1 & Sampel 1 & $500 \mathrm{~mL}$ & 0,2 \\
2 & Sampel 2 & $500 \mathrm{~mL}$ & 0,4 \\
3 & Sampel 3 & $500 \mathrm{~mL}$ & 0,5 \\
\hline
\end{tabular}

Skrining fitokimia terpenoid dan minyak atsiri menunjukan hasil positif. Skrining minyak atsiri memberikan aroma khas kulit jeruk dari residu hasil penguapan sedangkan hasil skrining terpenoid menunjukan terbentuknya cincin kecoklatan setelah penambahan asam sulfat pekat. Hasil skrining terpenoid dapat dilihat pada Gambar 1.

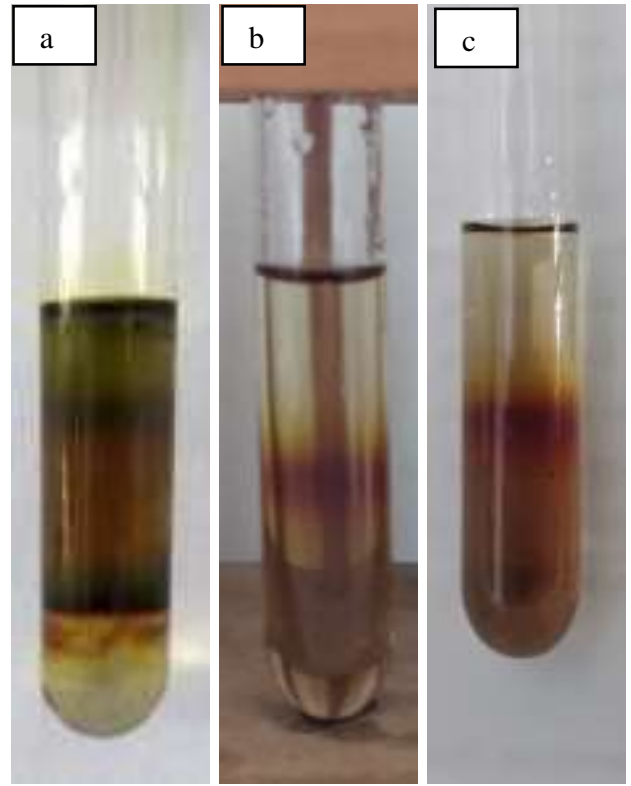

Gambar 1. Hasil skrining terpenoid sampel 1 (a), sampel 2 (b), sampel 3 (c)

Identifikasi selanjutnya yang dilakukan dengan KLT dan pengamatan dilakukan di bawah lampu UV $254 \mathrm{~nm}$ dan $366 \mathrm{~nm}$. Pada pengamatan di bawah lampu UV 254 teramati adanya pemadaman bercak yang dapat dilihat pada Gambar 2. Pengamatan yang dilakukan pada lampu UV $366 \mathrm{~nm}$ menunjukan terjadi fluoresensi biru yang dapat dilihat pada Gambar 3. Berdasarkan pengamatan nilai Rf pada sampel 1, sampel 2, dan sampel 3 masing-masing sebesar 0,$50 ; 0,58$; dan 0,57 .

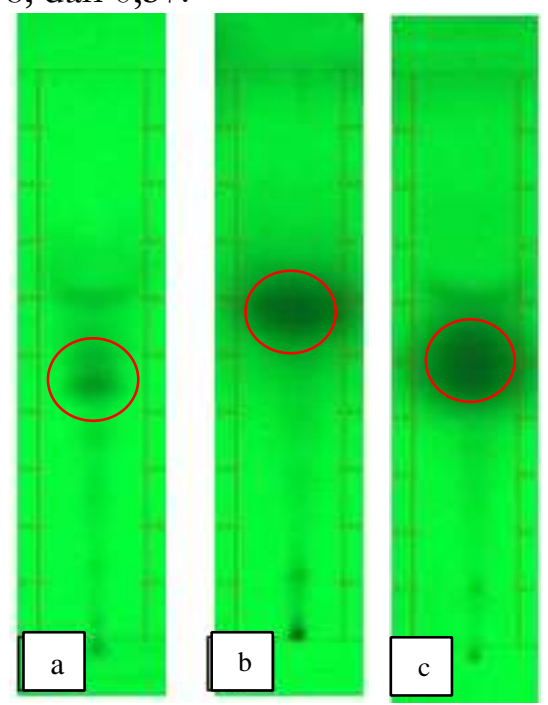

Gambar 2. Pengamatan di bawah sinar UV 254 nm MA1 (a), MA2 (b), MA3 (c)
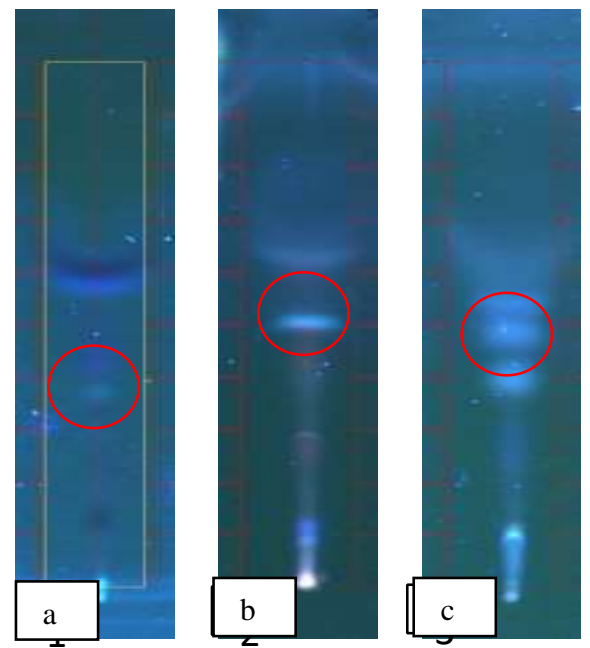

Gambar 3. Pengamatan di bawah sinar UV 254 nm MA1 (a), MA2 (b), MA3 (c)

Spektrum yang dihasilkan pada MAl 1, MA2 dan MA3 menunjukkan adanya senyawa linalool pada panjang gelombang $227 \mathrm{~nm}, 236$ $\mathrm{nm}$, dan $236 \mathrm{~nm}$. Senyawa linalool pada penelitian ini diperoleh nilai AUC pada MA1, MA2, dan MA3 berturut-turut sebesar 8980; 35889; 39475. MA3 memberikan nilai AUC senyawa linalool yang paling tinggi dibandingkan dengan MA1 dan MA2. 


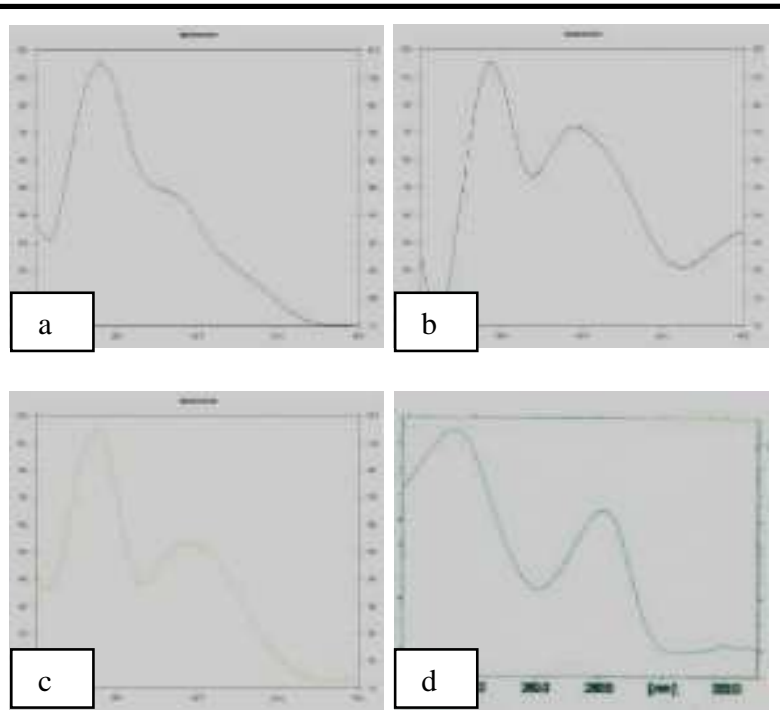

Gambar 4. Perbandingan spektrum linalool MA1 (a), MA2 (b), MA3 (c), dan pustaka spektrum linalool (d)

\section{PEMBAHASAN}

Senyawa linalool merupakan senyawa golongan monoterpen dan salah satu komponen penyusun minyak atsiri pada kulit buah jeruk manis (Citrus sinensis L.) (Switaning dkk., 2010). Skrining fitokimia ekstrak kulit buah jeruk manis pada sampel 1, 2 dan 3 menunjukkan bahwa ekstrak kulit buah jeruk manis mengandung senyawa golongan terpenoid dan minyak atsiri. Skrining fitokimia pada golongan terpenoid, diperoleh hasil positif yang ditandai dengan terbentuknya cincin berwarna kecoklatan. Skrining fitokimia pada ekstrak menunjukkan hasil positif pada golongan minyak atsiri yang ditandai dengan aroma khas jeruk dari residu larutan uji (Ciulei, 1984).

Proses perajangan bertujuan untuk membuka kelenjar minyak secara optimal, sehingga terjadi penguapan minyak atsiri dari sampel lebih cepat saat proses ekstraksi selain itu pengecilan ukuran partikel juga agar meningkatkan luas permukaan kontak ketika diekstraksi (Yustinah dan Fanandara, 2016).

Pemisahan minyak atsiri kulit buah jeruk manis menggunakan metode destilasi uap. Destilasi uap memungkinkan terjadinya hidrodifusi uap air kedalam jaringan sel tanaman sehingga pecah dan menyebabkan minyak akan terdorong keluar (Abdjul dkk., 2013). Kelenjar minyak diantara Flavedo dan Albedo pada kulit jeruk akan terbawa dengan mudah oleh uap air setelah dinding sel pada kulit jeruk pecah atau lisis. Dinding kulit jeruk yang lisis disebabkan oleh kontak antara uap air dengan kulit jeruk. (Alfianur, 2017).

Hasil yang diperoleh menunjukkan rendemen minyak atsiri pada sampel 1, sampel 2, dan sampel 3 berturut-turut yaitu $0,2 \% ; 0,4 \%$ dan $0,5 \%$. Hal ini sesuai dengan pernyataan bahwa pemanasan berpengaruh terhadap rendemen minyak atisiri yang diperoleh. Kusuma dan Uswatun (2014). Hal ini dikarenakan pada simplisia basah memiliki kelembaban yang tinggi sehingga menghambat minyak atsiri keluar. Menurut Muhtadin dkk. (2013) pemanasan dengan oven dapat membuka pori-pori pada kulit jeruk manis. Semakin banyak dan besar pori-pori yang terbuka meningkatkan penguapan dari minyak atsiri pada sampel. Sampel 3 memiliki rendemen yang paling tinggi disebabkan oleh pemanasan yang lebih lama dimana pori-pori pada sampel 3 lebih terbuka sehingga semakin banyak rendemen minyak atsiri yang dapat menguap.

Senyawa linalool yang diidentifikasi dengan menggunakan KLT-Spektrofotodensitometri pada panjang gelombang maksimumnya yaitu $235 \mathrm{~nm}$ (Desmiaty dkk. 2017), dilakukan dengan mengamati kesamaan bentuk spektrum seperti pada Gambar 4. Keberadaan senyawa linalool positif pada sampel MA1, MA2, dan MA3 dilihat dari spektrum yang ada. Rf linalool yang dihasilkan pada MA1, MA2, dan MA3 berturutturut sebesar 0,50;0,58;0,57.

Spektrum yang dihasilkan pada sampel MA1, MA2 dan MA3 menunjukkan adanya senyawa linalool pada panjang gelombang 227 $\mathrm{nm}, 236 \mathrm{~nm}$, dan $236 \mathrm{~nm}$. Senyawa linalool pada penelitian ini diperoleh nilai AUC pada MA1, MA2, dan MA3 berturut-turut sebesar 8980; 35889; 39475. Sampel MA3 memberikan nilai AUC yang paling tinggi. Peningkatan nilai AUC menunjukkan konsentrasi dari senyawa linalool meningkat, hal tersebut dapat disebabkan oleh 
pISSN: 2301-7716; eISSN: 2622-4607

Suardhika dkk.

Jurnal Farmasi Udayana, Vol 7, No 2, Tahun 2018, 38-43

pra-perlakuan yang dilakukan pada sampel kulit buah Jeruk. Pra-perlakuan dengan menggunakan pemanasan oven selama 48 jam dapat digunakan untuk memperoleh senyawa linalool yang lebih banyak pada sampel kulit buah jeruk manis. Hasil yang ditunjukkan pada spektrum berbeda dengan hasil yang didapatkan oleh Desmiaty dkk. (2017) yang menyatakan bahwa standar linalool memberikan serapan panjang gelombang maksimum pada panjang gelombang $235 \mathrm{~nm}$. Perbedaan panjang gelombang dapat disebabkan oleh efek pelarut yang digunakan. Pelarut dapat menyebabkan pembembentukan ikatan hidrogen yang dapat mempengaruhi konjugasi molekul sehingga berpengaruh terhadap panjang gelombang maksimum. Pada sampel 1 mengalami pergeseran hipsokromik yaitu pergeseran absorban ke daerah panjang gelombang yang lebih pendek. Sedangkan pada sampel 2 dan 3 terjadi pergeseran batokromik yaitu pergeseran absorbansi ke daerah panjang gelombang yang lebih panjang (Dachriyanus, 2004).

\section{KESIMPULAN}

Berdasarkan hasil penelitian yang dilakukan dapat disimpulkan bahwa terdapat pengaruh secara langsung dari proses pengeringan dengan menggunakan oven terhadap rendemen minyak atsiri yang diperoleh. Didapatkan hasil pada ekstraksi kulit jeruk segar diperoleh rendemen sebesar $0.2 \%$, pada sampel kulit jeruk yang dikeringkan selama 24 jam diperoleh rendemen sebesar $0.4 \%$, dan pada sampel kulit jeruk yang dikeringkan selama 48 jam diperoleh rendemen sebesar $0.5 \%$. identifikasi lonalool dengan menggunakan KLT-Spektofotodensitometri menunjukan peningkatan AUC seiring lamanya pengeringan.

\section{UCAPAN TERIMA KASIH}

Penulis mengucapkan terimakasih kepada dosen pembimbing, teman-teman dan semua pihak yang telah sangat membantu dalam penelitian ini.

\section{DAFTAR PUSTAKA}

Abdjul N, M. Paputungan, dan S. Duengo. 2013. Analisis komponen minyak atsiri pada tanaman nilam hasil destilasi uap air dengan menggunakan KG-SM.

Ciulei, J. 1984. Methodology for Analysis of Vegetable and Drugs. Romania: Faculty of Pharmacy.

Gandjar, I.G., dan Rohman, A. 2007. Kimia Farmasi Analisis. Yogyakarta: Pustaka Pelajar.

Khotimah, R.P., dan Masduki. 2016. Improving Teaching Quality and Problem Solving Ability Through Contextual Teaching and Learning in Different Equation: A Lesson Study Approach. Journal of Research and Advances in Mathematics Education. Vol. 1(1): 1-13.

Kusuma, T. M. dan Uswatun, N. 2014. Isolasi dan Identifikasi Minyak Atsiri dari Simplisia Basah dan Simplisia Kering Daun Sirih Merah (Piper crocatum). Pharmacy. Vol. 11(1): $1-4$.

Muhtadin, A. et., R. Wijaya, Mahfud. 2013. Pengambilan Minyak Atsiri dari Kulit Jeruk Segar dan Kering Dengan Menggunakan Metode Steam Distillation. Jurnal Theknik Pomits. Vol. 2 (1): 98-101.

Nugraheni, S.N., L.U. Khasanah, R. Utami, B.K. Ananditho. 2016. Pengaruh Perlakuan Pendahuluan dan Variasi Metode Destilasi Terhadap Karakterisik Mutu Minyak Atsiri Daun Kayu Manis (C. burmanii). Jurnal Teknologi Hasil Pertanian. Vol 9. (2): 51-59.

Padmasari, P.D., K.W. Astuti, N.K. Warditiani. 2013. Skrining Fitokimia Ekstrak Etanol 70\% Rimpang Bangle (Zingiber purpureum Roxb.). Jurnal Farmasi Udayana. Vol. 2(4): 14. 
Pramono, E. 2002. The Commercial Use Of Traditional Knowledge And Medicinal Plants In Indonesia. Submitted For MultiStakeholder Dialoque On Trade, Intellectual Property And Biological Resources In Asia. Jakarta: Airlangga.

Switaning, R., Fajari, N. \& Dwi, M., 2010, Ekstraksi Minyak Atsiri Dari Limbah Kulit Jeruk Manis Di Desa Gadingkulon Kecamatan Dau Kabupaten Malang sebagai Campuran Minyak Goreng Untuk Penambah Aroma Jeruk. Laporan Penelitian. Malang: Universitas Negeri Malang.
Yustinah, dan Fanandara, D. 2016. Ekstraksi Minyak Atsiri dari Kulit Jeruk Sebagai Bahan Tambahan pada Pembuatan Sabun.Konversi. 5(1):25-30.

Sunardi, Fatriani, Husnul, C.H. 2008. Pengaruh Pola Pengeringan Terhadap Rendemen dan Kualitas Minyak Atsiri Daun Nilam (Posgostemon calbin). Jurnal Hutan Tropis Borneo. Vol. 9(22): 7-16.

Zahra, S., Iskandar, Y. 2017. Kandungan Senyawa Kimia dan Bioaktivitas Ocimum basilicum L. Farmaka. Vol. 15(3): 143-150. 